International Journal of Applied Linguistics \& English Literature

ISSN 2200-3592 (Print), ISSN 2200-3452 (Online)

Vol. 1 No. 3; July 2012 [Special Issue on World Literature in English]

\title{
A Hermeneutic Approach to a Socio-cultural Study of Ian McEwan's On Chesil Beach
}

\author{
Mina Abbasiyannejad \\ Universiti Putra Malaysia, Malaysia \\ Rosli Talif \\ Universiti Putra Malaysia, Malaysia
}

Received: 10-07- 2012

Accepted: 25-07- 2012

Published: 31-07- 2012

doi:10.7575/ijalel.v.1n.3p.29

URL: http://dx.doi.org/10.7575/ijalel.v.1n.3p.29

\begin{abstract}
Ian McEwan's On Chesil Beach is the story of conflicts at various levels. In this novella, the author shows how different factors, particularly cultural norms and sexual conflicts can affect people's lives and lead them down a certain path. Using a hermeneutic approach, this paper discusses the influential socio-economic, political, and cultural factors that had great impact on people's lives. McEwan illustrates how circumstances and settings influence people's livelihoods and how the socio-economic status of the characters plays an important role in determining their future conditions. This essay shows the influence of culture, including the social climate of the time, on the society's attitudes towards sexuality, class differences, legislation, contraceptives, abortion and - most of all — on the personal lives of the characters in On Chesil Beach.
\end{abstract}

Keywords: Class and sexual repression, contraception and abortion, identity, sexuality as taboo

\section{Introduction}

Dallmayr (2009) states that "hermeneutics means the theory, or rather the practice or art of interpretations. In its primary and traditional sense, interpretation means textual interpretation, that is, the encounter between a reader and a text" (23).

Culture is "not simply a reflection of economic and political systems, but nor can it be independent from it" (Barry 183). This study is an attempt to read the book for possible practical "applications" of the hermeneutical perspective in the social and cultural domains. McEwan was a controversial writer who challenged the different traditions in the society of his time and commented on how they affected the lives of the people. A hermeneutic study of the novel provides an opportunity to interpret and understand the historical, socio-cultural, religious, and political climate of the time and their impact on other characters.

Malcolm, in his book Understanding Ian McEwan asserts that "McEwan's early works mostly dealt with dark themes and [he] had been known as a writer obsessed with "the perverse, the grotesque, and the macabre"" $(2002,4)$. But there is a shift of themes from these issues to socio-cultural issues. Roberts in his interview with Ian McEwan asked the author why he set the relationships in his novels against external forces or individuals, and in On Chesil Beach "exploring the intimacies associated" with the characters. McEwan's states that "We are social creatures, and relationships are where we live, unless our lives are spent tragically alone" (Roberts 2008). The year 1962 "stands on the cusp of that huge shift in sexual relations, but also social relations," McEwan told Robert Siegel in an interview in 2007.

One of the salient issues deals with sex - the most personal aspect of a person's life. On Chesil Beach is the story of an ultimate relationship in which the protagonists are hopelessly inadequate in facing the problem of their sexuality. McEwan tactfully brings about the situation that reveals their lack of experience when it comes to sex. Their inexperience is the result of cultural barriers of the time that did not provide the opportunity for young people to be adequately informed and prepared in matters of sex and sexual behavior.

Identity is closely related to, and often described as being, a product of place and its cultural associations. Therefore, a study of this subject can be helpful in highlighting the pivotal effects of social environment on people. Identity is a combination of various factors that include self-esteem, motivation, and emotional experience. 
International Journal of Applied Linguistics \& English Literature

ISSN 2200-3592 (Print), ISSN 2200-3452 (Online)

Vol. 1 No. 3; July 2012 [Special Issue on World Literature in English]

In On Chesil Beach, the story is set in 1962 - a time of rigid sexual boundaries. It was not easy for people then to talk about sexuality and, therefore, their problems remained unexplored. Christina Byrnes, in her book Sex and Sexuality in Ian McEwan's Works,comments "McEwan's portrayal of sexuality is to highlight various aspects of relationship, interpersonal communication, closeness, and distance, status and the acting out of erotic fantasy" (5).

Most people in the society of the early 1960s never openly mentioned their sexuality and when they did, they experienced feelings of shame and disgrace. Ferriter explains the constraint of sexuality in the 1960s when Tom Inglis recalls "in the 1960s, every time the subject of sex surfaced on radio or television, his father 'got up from his chair and walked out of the room." Ferriter also suggests there was a continuing ignorance about the facts of life and "an inability of husbands and wives to communicate their fears, needs and desires and, consequently, to negotiate when and how they wanted to have sex" (Ferriter 3).

Another problem of the young at that time was limitation of birth control devices, and the existence of anti-abortion laws which had adverse effects on the sexual behavior of the young then. This study will explore relevant legislation pertaining to contraception and abortion. Viewing sexuality as taboo is only one aspect of the book; social class also plays an important role in people's relationships. McEwan portrays class difference and its outcome in the story by describing in detail and comparing the homes of Florence's family and Edward's, their lifestyles, manners, and language codes. He shows how people belonging to a lower class are less refined in the eyes of the more affluent class. On Chesil Beach is a mixture of all of the above-mentioned conflicts. The newly-wed protagonists are about to start their lives in such an era with all of its complexities and challenges. This study attempts to shed light on the problematic issues of the critical time of the 1960s and their consequences on social life.

\section{Cultural attitudes towards sexuality}

Edward and Florence are both young and inexperienced in sexual matters. They are expected to do something both have never done before. They live in an era when even the mere discussion of sex is considered taboo. Culturally, sex is only acceptable within marriage. Reynolds et al. mention that,

In the period 1950-70, strong disapproval of sexual relations outside marriage was coupled with the financial means to enter marriage - a strong incentive to wed. Not surprisingly, the age at marriage fell significantly. The social pressure to confine sexual activity, domestic partnership, and childbearing within legal marriage has diminished dramatically, and rates of cohabitation and extramarital childbearing have risen accordingly. (12)

Florence not only suffers from lack of experience but her problem is even worse when she cannot reveal it to her friends or even her mother. "Ruth, her sister was too young and her mother, perfectly wonderful in her way, was too intellectual, too brittle, an old fashioned bluestocking" (10). As for her friends, "she could not trust them with a secret" (11). She feels alone without help and the only thing she has is a paperback manual. "She was alone with a problem....all she had in the way of wisdom was her paperback guide" (11).

McEwan portrays Edward as a typical young man of the time. He emphasizes Edward's circumstances and explains that during his three years as a student, the nights at the club represented the peak of his cultural experience, and for years to come, he considered that this was the music that formed his tastes, and even shaped his life $(38,39)$.

However, Ferriter refers to Bestic's belief that the English might be more physically suppressed compared to the Irish, and that they would not talk about sexual intercourse even within the matrimonial home on account of "fear, guilt and ignorance." Further, they were overmodest about sex education in schools, with only a handful of schools producing guides on the subject. In general, the domain of English sex life was "tortuous, paradoxical, and dangerous." In fact, the so-called sex revolution in England of the 1960s was generally confined to London and the South East. Jonathan Green is of the opinion that the 1960s, as generally recognized, is full of myths and all things in the myths relate to sex and that the actual revolution blossomed only in the 1970s (Ferriter, 4).

McEwan clearly highlights the existence of sexual repression throughout the Victorian era when there was a rigid and strict rule for it and the ideal woman was the most innocent and sexually ignorant. Edward confirms this when he states to Florence "you don't have the faintest idea how to be with a man. You carry on as if it's 
International Journal of Applied Linguistics \& English Literature

ISSN 2200-3592 (Print), ISSN 2200-3452 (Online)

Vol. 1 No. 3; July 2012 [Special Issue on World Literature in English]

eighteen sixty-two. You don't even know how to kiss" (144). De Waard, in his article "Agency and Metaphor in the Neo-Victorian Imagination: The Case of Ian McEwan," considers the novella On Chesil Beach "the most elaborate neo-Victorian one text to date." He believes that despite the fact that the novel is set in 1962, the plot examines the way that newlyweds are under the pressure of "rigid social structure whose fixed class and gender barriers are constructed as relics from the Victorian past" (154).

$\mathrm{He}$ also explains that "McEwan's ambition to reinstall a $19^{\text {th }}$-century, secular and scientific humanism is in evidence in many of his interviews and public performances" (footnote, 145). In an interview with Rose in 2007, he admits that he deliberately chose the setting of Chesil Beach because on one side there is the English Channel, and on the other side there is a lagoon that is narrow and steep, it's a sort of trap, "all English constraints of their time" (Rose 2007).

\section{Social class}

McEwan's portrayal of the contrasting social status of Edward and Florence is ingenious. He shows the differences in every aspect of their lives, including food, clothes, behavior, housing, music and even their hotel experiences. He artistically focuses on the differences to show how many things between the couple in love are similar as well as different. Edward belongs to the middle class with a father who is a school teacher with a moderate income - only enough to live in the country, and a brain damaged mother without any nurse to take care of her. Florence, on the other hand, comes from upper class society and enjoys the affluence associated with her class. Florence's mother is an academic lecturer who "was too intellectual, an old fashioned bluestocking" (10), and her father, a successful businessman.

In the same interview with Rose, McEwan states that, he "tries to place them socially" by presenting Florence as coming from a "large villa on the north side down the Wood stuck rose," while Edward comes from a "rather humble, rather squalid household in the Chiltern Hills" (Rose 2007). Kakutani (2007), in her review of On Chesil Beach, for example, agrees on the stark difference between the socio-cultural backgrounds of Edward and Florence: "[...] Florence comes from a snooty, upper-class family [...] Edward grew up in a hard-scrabble, chaotic household $[\ldots] "$

Perhaps what complicates the picture is the fact that Florence's father hires Edward. This can be seen as an instance of one class reluctantly accommodating another (lower) class. They live in a time when, normally, men are solely responsible for the upkeep of the family. Obviously, Edward is not enthusiastic about being (socially and economically) inferior to Florence. He does not even have a stable job "Edward was working at various temporary jobs, principally as a grounds man for a cricket club" (57). When they later argue about money and jobs, Edward refuses to work for Florence's father, saying angrily "I have never cared about money, yours or anyone's. Keep your money, your father's money. I don't want to work for your father. You think I wheedled that job out of you? It was your idea. And I don't want it. She knows that she has offended him deeply, even more than she intended" (147).

McEwan's reference to class difference is highlighted in another ground breaking novel, Atonement. Cecilia, the protagonist who belongs to upper class English society, falls in love with Robbie, son of the servant of the house. Cecilia's father pays all the education fees for Robbie "Her father had subsidized Robbie's education all his life" (40). At a later stage in the novel, Robbie, who in a way feels the same resentment as Edward does towards such patronage says he will repay Cecilia's father what he has spent on his education. "Look, I have agreed to pay your father back" (41). In a way, it is reminiscent of Florence's father accommodating Edward, who resents the situation.

The other socio-cultural indicators of status found in the story include having experience of hotels, choice of food, even sports and music. Regarding hotel experience, Edward has never been in a hotel before his wedding night, and he never talks about it. "Edward did not mention that he had never stayed in a hotel before [...] whereas Florence is an old hand" (3). Appropriate to one of her class, Florence listens to and plays classical music; Edward's preference is for rock music, typical of the choice of his social class. Florence is a violinist and practices five hours a day, while Edward "had never cared for classical music" (14). Florence is used to hanging out at concert halls and tea-rooms in her London neighborhood, while Edward frequents the pubs of Fitzrovia and Soho. McEwan even goes further and highlights Edward's class by mentioning his choice of clothes "None of his socks matched. He had only one tie, narrow, knitted, dark blue, which he wore nearly all the time" (10). 


\section{Contraception and abortion}

The other controversial issue is the use of contraceptives. It is reasoned that people avoid sex because there is no proper way to prevent pregnancy. McEwan portrays the situation of sexual relationships and the consequences in this way:

A couple of friends, both decent footballers, went down this route, were married in their second year and disappeared from view. One of these unfortunates made a particular impact as a cautionary tale. He got a girl from the University administration office pregnant and was, in his friends' view 'dragged to the altar' and not seen for a year, until he was spotted in Putney High Street, pushing a pram, in those days still a demeaning act for a man. (39)

He also points out that "the pill was a rumor in the newspaper, a ridiculous promise" (39). Furthermore, the history of the pill shows that up until 1961, they were only available to married women (BBC News, 1999). It is also written that the pill was used "only by the minority of women in North America in the 1960s, and, in the 1970 s, $18 \%$ of French couples still relied on the withdrawal method, while only $6 \%$ of French women were on the pill in 1970" (Ferrier 3,4). McEwan states that in "1962 pills are not quite arrived in England" (Rose, 2007). While Glasier et al. assert that "emergency contraception first became available in Europe in the late 1960s and early 1970s" (49).

Luker in "Sex Education, the Sexual Revolution and the Sixties" says that pregnancy out of wedlock was such a shameful situation that women who got pregnant outside wedlock were hidden, advised to give up their babies for adoption and encouraged to restart a "normal" existence as quickly as possible. Even in the USA, in 1970, an unmarried mother in Massachusetts, who made the decision to scoff the tradition and hold onto her baby, faced dire consequences. She was relieved of her job and even diaper sellers refused her business. It was also not uncommon for unmarried men to be refused condoms by pharmacists (143).

So these categories of people were quite vulnerable and, therefore, avoided having sex. Weinberg et al. state that "this is a time that sexual experience for women takes place only within marriage. And as a consequence women depend on men to awaken their sexual potential" (3). McEwan portrays the strict rules of female hostels and girls' condition as follows,

Florence was on the other side of town, near the Albert Hall, in a prim hostel for female students, where the lights went out at eleven and male visitors were forbidden at any time, and girls were always popping out of each other's rooms. (40)

They are not only limited by the Hostel or other institutions but they also have their own limitations from their home.

The few girls he knew - there were not so many at universities in those days - travelled in for lectures from the outer suburbs and left in the late afternoon, apparently under strict parental instruction to be home by six. Without saying so, these girls conveyed the clear impression that they were 'keeping themselves' for a future husband. There was no ambiguity — to have sex with any one of these girls you would have to marry her. (39)

Regarding the separation of boys and girls, McEwan reveals that "It was as though the young women had entered a convent. Since it did not seem possible to go out with a boy and still keep up with old friends, Florence preferred to stick with her hostel group" (43). The 1960s also came with radical changes. A sexual trend premised on the productive and breeding married couple was the favored life style. Abortion and contraceptive devices were illegal. Although contraceptive centers were in existence, the combined influence of societal mores and state laws diminished their coverage and they catered for only married people. Further, some states did not even have such clinics. The common contraceptives for the married couples of that time were withdrawal and douching and the use of condoms (Luker 141-142). 
International Journal of Applied Linguistics \& English Literature

ISSN 2200-3592 (Print), ISSN 2200-3452 (Online)

Vol. 1 No. 3; July 2012 [Special Issue on World Literature in English]

\begin{abstract}
Abortion law
Another significant factor which plays a significant role in people's relationships is abortion. If pregnancy happens as a consequence of a sexual liaison, getting rid of it was not as easy as today. By having a short glimpse on the history of abortion law and its eligibility, one can conclude that it was really a significant factor.

As early as the 1950s, support for the reform of abortion laws grew. The 1960s ushered in more awareness and practice of fertility control. This phenomenon was facilitated in no small way by the maturation of the women's movement. Still, many who resorted to illegal abortion died or suffered complications. However, in 1967, the Abortion Act (sponsored by David Steel, MP), which legalized abortion under certain conditions, became law and became operational on 27 April 1968. ("History of Abortion Law in the UK", 1967). Morton in the article "Gender and Society" observes that that the "general trend toward liberalization in abortion laws around the world followed the passage of the British Act of 1967" (680).

Russell states that the eve of the 1970s and early 1970s was a period of acute social change, and many of the changes were about the evolution of women's roles in British society. The student as well as women's campaigns of the late 1960s and early 1970s facilitated changes in dispositions, political views, and laws concerning sexuality and gender roles (Lewis 1992). This period was occasioned by an increase in teenage pregnancies and child bearing (Russell 1982), and divorce (Office of Population Censuses and Surveys, 1977) as well as abortion rates (Lewis 1992). Finally, the 1967 Abortion Act, the 1969 Divorce Act, the 1975 Equal Pay Act, the 1975 Invalid Care Allowance, the 1976 Domestic Violence and Matrimonial Proceedings Act, and the Housing Act of 1977 (Lewis 1992 11), were designed to address women's demands for equality at home and in the workplace $(489,490)$.

\section{Conclusion}

McEwan's shift from his preoccupation with the macabre in his early novels to social and cultural themes in his late novels gives the reader a new insight into his works. In On Chesil Beach we encounter a novel that challenges the repression of class and sexuality, which directly and indirectly affect people's lives. On Chesil Beach is the story of conflicts in various dimensions, which dominated the society of the 1960s, the historical context of the novel. Both the characters go through much personal anguish and suffer from their inability to accomplish a satisfying relationship mainly because of the prejudices of their time and their subsequent personal inadequacies. The period is significant in painting a picture of the social and cultural repressive attitudes towards sex and sexuality, existence of rigid laws on abortion and birth control, and ultimately, class difference. It is Edward's social status that makes him feel inferior and he is found wanting before Florence, who belongs to the wealthy privileged class. McEwan competently portrays the direct and indirect impact of culture and society on people's lives and how, inevitably, people suffer the consequences. Even though he explores the impact of cultural issues, he does not deny the person's own decisions when he says "the entire course of a life can be changed by doing nothing" (166). And Edward is guilty of doing nothing.
\end{abstract}

\title{
References
}

“A short history of the pill.” Web. 23 July 2010.

Barry, Peter. Beginning Theory: An Introduction to Literary and Cultural Theory. Manchester: Manchester University Press, 2002. Print.

Dallmayr, Fred. "Hermeneutics and Inter-Cultural Dialog: Linking Theory and Practice." Ethics \& Global Politics 21 (2009): 23-39. Print.

De Waard, Marco. "Agency and Metaphor in the Neo-Victorian Imagination: The Case of Ian Mcewan." REAL: Yearbook of Research in English and American Literature 25 (2009): 145-61. Print.

Ferriter, Diarmaid. Occasions of Sin: Sex and Society in Modern Ireland. London: Profile Books, 2009. Print.

Glasier, Anna, et al. "Emergency Contraception in the United Kingdom and the Netherlands." Family Planning Perspectives 282 (1996): 49-51. Print.

"History of Abortion Law in the UK." Web. 6 August 2010.

Kakutani, Michiko. "Past and Present: Imperfect, Tense.” The New York Times. Web. 1 June 2007. Print.

Malcolm, David. Understanding Ian McEwan. C Columbia: University of South Carolina Press, 2002. Print. 
International Journal of Applied Linguistics \& English Literature

ISSN 2200-3592 (Print), ISSN 2200-3452 (Online)

Vol. 1 No. 3; July 2012 [Special Issue on World Literature in English]

McEwan, Ian. Atonement. London: Vintage, 2001. Print.

McEwan, Ian. On Chesil Beach. Random house: London, 2007. Print.

Morton, Christine. "Abortion in the USA and the UK." Gender and Society 205 (2006): 680-81. Print.

Reynolds, Jenny, and Penny Mansfield. "The Effect of Changing Attitudes to Marriage on Its stability." High Divorce Rates: The State of the Evidence on Reasons and Remedies. Research Series 1 (1999): 1-38. Print.

Roberts, Ryan. "A Thing One Does": A Conversation with Ian McEwan. Jackson: University Press of Mississippi, 2008. Print.

Rose, Charlie. “A conversation with Ian McEwan.” 2007. Web. 20 August 2010.

Russell, Stephen. "Life Course Antecedents of Premarital Conception in Great Britain." Journal of Marriage and Family 562 (1994): 480-92. Print.

Siegel, Robert. “Ian McEwan's 'On Chesil Beach.” National Public Radio. Web. 1 June 2007.

Weinberg, M.S., R.G. Swensson, and S.K. Hammersmith. "Sexual Autonomy and the Status of Women: Models of Female Sexuality in US Sex Manuals from 1950 to 1980." Social Problems 303 (1983): 312-24. Print.

\section{Mina Abbasiyannejad}

Mina is currently a $\mathrm{PhD}$ student at the Faculty of Modern Languages and Communication, Universiti Putra Malaysia, Malaysia. She received B.A in English Literature from Persian Gulf University (Booshehr), and M.A from Shiraz University (Iran).

\section{Rosli Talif}

Rosli is an associate professor of English at the Faculty of Modern Languages and Communication, Universiti Putra Malaysia (UPM). He received his PhD from the University of Nottingham, England in 1992. His research interests include Literature in ESL and Reading, Literature and Gender, and Language Policy and Planning in Malaysia. His publications interlink language and literature while re-examining existing paradigms that affect the way we conceptualize the roles, functions, and developments of language and literature in society. 